\title{
Evaluation methods for ceramic suitability of raw clays
}

\author{
M. Hajjaji \\ Laboratoire de Physico-chimie des Matériaux et Environnement, Unité Associée au CNRST (URAC 20), \\ Département de Chimie, Faculté des Sciences Semlalia, Université Cadi Ayyad, BP. 2390, Marrakech, Morocco
}

\begin{abstract}
Ceramic suitability of kaolinitic-illitic and chloritic-illitic raw clays was assessed by methods involving microstructure investigation and ceramic properties measurements, some reported diagrams and response surface methodology (RSM). Results of the former method showed that all clays are suitable for red stoneware tiles. The stoneware manufacturing is facilitated by the marked reduction of porosity due to the flow of melt, mainly originated from the breakdowns of illite. This result was partially supported by the use of a diagram involving the chemical composition of clays as well as by the RSM results. According to the later method, bricks may be manufactured under restricted firing conditions and stoneware tiles could be prepared at temperatures as low as $950^{\circ} \mathrm{C}$.
\end{abstract}

\section{INTRODUCTION}

Naturally occurring clays consisting of plastic materials (clay minerals), fillers (quartz) and fluxes (feldspars) are appropriate feeding materials for traditional ceramics manufacturing [1]. However, their suitability depends on inherent characteristics (chemical and mineralogical compositions, grain size and plasticity) and extrinsic factors (firing cycle parameters, operating atmosphere and shaping methods) [e.g. [2-4]]

Commonly, for assessing the ceramic suitability of clays the change of the microstructure of fired samples against operating factors are investigated, and their technical properties are determined. Empirical diagrams involving grain size distribution and chemical or mineralogical composition also are used $[5,6]$. Recently, regression models implying response surface methodology (RSM) have been used [7,8]. In the later case, the desirability domains for manufacturing different kinds of ceramic products are defined.

In this work, the ceramic suitability of clays is evaluated based on the results of the firing transformations and ceramic properties measurements, as well as by the use of some reported diagrams and response surface methodology. For the later method, a particular attention was paid to the influence of firing cycle parameters on common ceramic properties.

\section{MATERIALS AND EXPERIMENTAL PROCEDURES}

The studied clays labeled RA, RO and RS were from Tassaouat, Ourika valley and Safi (Morocco) respectively. Their chemical and mineralogical compositions are reported in Table 1.

The grain size $<2 \mu \mathrm{m}$ and $>20 \mu \mathrm{m}$ fractions of clays were isolated by sedimentation according to the Stokes' law. The Atterberg's limits, namely the liquidity and plasticity limits (LL, PL) were conventionally determined, and the index of plasticity (PI) was deduced: PI $=\mathrm{LL}-\mathrm{PL}$.

Prismatic samples $\left(4 \times 10 \times 40 \mathrm{~mm}^{3}\right)$ were shaped by extrusion from damped clays (26wt.\% humidity) and gently dried. Then, they were heated in an electric furnace, operating in open atmosphere. The investigated heating temperature $(\mathrm{T})$, soaking time $(\mathrm{t})$ and heating rate $(\mathrm{h})$ were in the ranges $800-1150^{\circ} \mathrm{C}, 10-300 \mathrm{~min}$ and $1-20^{\circ} \mathrm{C} / \mathrm{min}$ respectively.

Shrinkage (FS), bending strength (BS) and Water absorption (WA) of fired samples were measured as described in [9]. Crystalline phases in fired samples were identified by X-ray diffraction (XRD), and microstructure of shards was examined by scanning electron microscope (SEM).

Table 1. Chemical and mineralogical compositions (wt.\%) of the studied clays.

\begin{tabular}{|c|c|c|c|c|c|c|c|}
\hline \multicolumn{4}{|c|}{ Chemical composition } & \multicolumn{4}{|c|}{ Mineralogical composition } \\
\hline & RA & $\mathrm{RO}$ & $\mathrm{RS}$ & & RA & $\mathrm{RO}$ & RS \\
\hline $\mathrm{SiO}_{2}$ & 50.8 & 44.2 & 53.2 & $\mathrm{~K}$ & - & 28 & 25 \\
\hline $\mathrm{Al}_{2} \mathrm{O}_{3}$ & 19.2 & 23.3 & 18.5 & I & 42 & 38 & 33 \\
\hline $\mathrm{Fe}_{2} \mathrm{O}_{3}$ & 9.4 & 9.1 & 6.4 & Q & 22 & 21 & 19 \\
\hline $\mathrm{MgO}$ & 4.3 & 5.1 & 2.2 & $\mathrm{H}$ & 8 & 6 & 4 \\
\hline $\mathrm{CaO}$ & 0.3 & 1 & 1.7 & $\mathrm{Ch}$ & 15 & - & 10 \\
\hline $\mathrm{Na}_{2} \mathrm{O}$ & 1.6 & 0.8 & 1.8 & Serp & 5 & - & - \\
\hline $\mathrm{K}_{2} \mathrm{O}$ & 4.3 & 8.7 & 4.4 & Do & - & - & 6 \\
\hline $\mathrm{TiO}_{2}$ & 0.8 & - & 0.7 & $\mathrm{~B}^{b}$ & 8 & 7 & 3 \\
\hline $\mathrm{LI}^{a}$ & 8.3 & 6.8 & 11 & & & & \\
\hline
\end{tabular}

${ }^{a}$ Loss on Ignition;

${ }^{b}$ Balance: feldspars, calcite, ...

K: kaolinite; I: illite; Q: quartz; H: hematite; Ch: chlorite; Serp: serpentine; Do: dolomite.

\section{MICROSTRUCTURE AND CERAMIC PROPERTIES}

The XRD analyses of fired samples showed that frameworks of chlorite, kaolinite and serpentine collapsed at $\mathrm{T}<850{ }^{\circ} \mathrm{C}$, and dehydroxylated illite persisted up to $950^{\circ} \mathrm{C}$ (Table 2). Particles of dehydroxylated illite manifested as interconnected filaments (Fig. 1).

As a consequence of the increase of temperature, $\mathrm{Mg}$-spinel and olivine, and sanidine formed in RA and RO samples respectively (Table 2). Also, melting 
Table 2. Minerals detected in clay samples fired at different temperatures.

\begin{tabular}{|l|l|l|l|l|l|l|l|l|}
\hline $\begin{array}{l}\mathrm{T} \\
\left({ }^{\circ} \mathrm{C}\right)\end{array}$ & 850 & 900 & 950 & 1000 & 1050 & 1075 & 1100 & 1125 \\
\hline RA & & $\mathrm{I}_{\mathrm{d}}$ & $\mathrm{I}_{\mathrm{d}}$ & $\mathrm{Q}$ & $\mathrm{Q}$ & $\mathrm{Q}$ & & \\
& & $\mathrm{Q}$ & $\mathrm{Q}$ & $\mathrm{H}$ & $\mathrm{H}$ & $\mathrm{H}$ & & \\
& - & $\mathrm{H}$ & $\mathrm{H}$ & $\mathrm{Sp}$ & $\mathrm{Sp}$ & $\mathrm{Sp}$ & - & - \\
& & $\mathrm{F}$ & $\mathrm{Sp}$ & $\mathrm{F}$ & $\mathrm{F}$ & $\mathrm{F}$ & & \\
& & & $\mathrm{O}$ & $\mathrm{O}$ & & \\
\hline RO & $\mathrm{I}_{\mathrm{d}}$ & $\mathrm{Q}$ & & $\mathrm{Q}$ & & $\mathrm{Q}$ & & \\
& $\mathrm{Q}$ & $\mathrm{H}$ & - & $\mathrm{San}$ & - & $\mathrm{San}$ & - & - \\
& $\mathrm{H}$ & & & $\mathrm{H}$ & & $\mathrm{H}$ & & \\
\hline RS & $\mathrm{I}_{\mathrm{d}}$ & $\mathrm{I}_{\mathrm{d}}$ & $\mathrm{Q}_{\mathrm{r}}$ & $\mathrm{Q}_{\mathrm{r}}$ & $\mathrm{Q}_{\mathrm{r}}$ & & $\mathrm{Q}$ \\
& $\mathrm{Q}$ & $\mathrm{Q}$ & $\mathrm{Q}$ & $\mathrm{Q}$ & $\mathrm{Q}$ & & $\mathrm{Q}$ & $\mathrm{S}$ \\
& $\mathrm{H}$ & $\mathrm{H}$ & $\mathrm{H}$ & $\mathrm{H}$ & $\mathrm{H}$ & - & $\mathrm{H}$ & $\mathrm{H}$ \\
& $\mathrm{Hr}$ & $\mathrm{Hr}$ & $\mathrm{Hr}$ & $\mathrm{Hr}$ & $\mathrm{Hr}$ & & $\mathrm{Hr}$ & $\mathrm{Hr}$ \\
& & & & & & & $\mathrm{L}$ & $\mathrm{L}, \mathrm{P}$ \\
\hline
\end{tabular}

$\mathrm{I}_{\mathrm{d}}$ : dehydroxylated illite; Q: quartz; H: hematite; F: feldspar; Sp: spinel; O: olivine; San: sanidine; Hr: hercynite; Or: orthose.

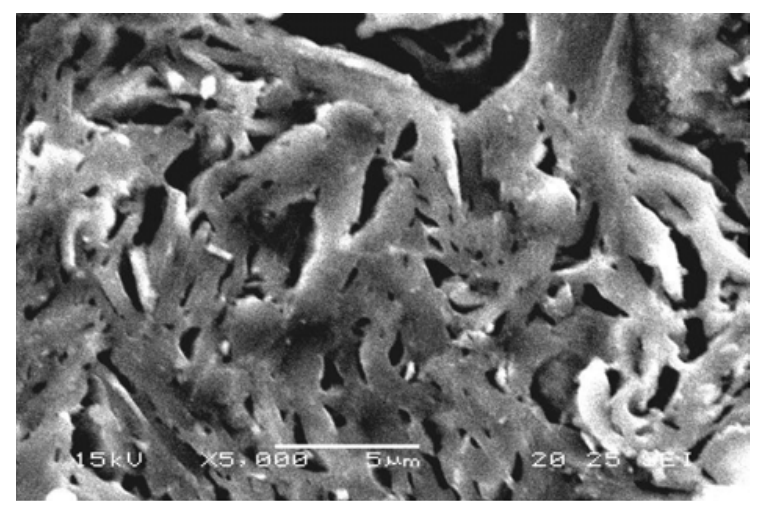

Figure 1. Interconnected particles of dehydroxylated illite formed in RA samples heated at $950^{\circ} \mathrm{C}$.

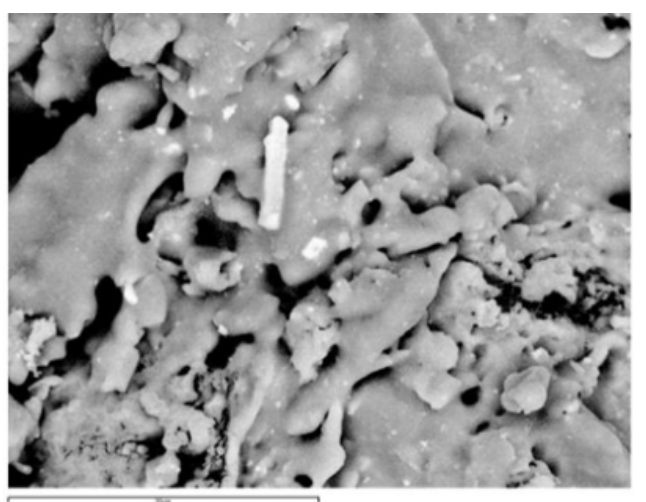

Figure 2. A vitrified matrix of BS sample fired at $1050^{\circ} \mathrm{C}$.

zones spread out across the matrix. In fired RS samples hercynite, labradorite, leucite, orthose and $\mathrm{Mg}$-spinel formed (Table 2). In addition, samples were the subject of intense vitrification (Fig. 2).

The variations of shrinkage, bending strength and water absorption versus firing temperature were determined (Fig. 3). These evolutions were chiefly linked to the formation of melt, which amount increased with the increase of temperature. The melt abundance observed at
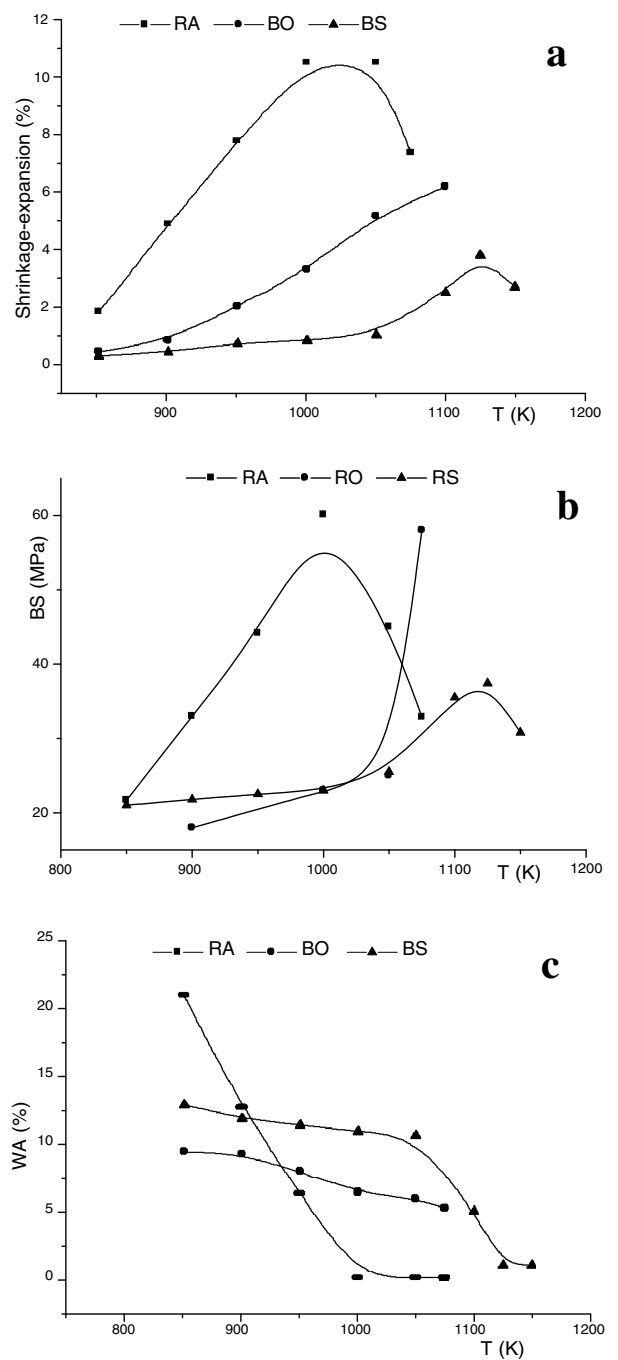

Figure 3. Variations of shrinkage (a), bending strength (b) and water absorption (c) versus firing temperature.

higher temperatures had adverse effects (bloating pores, warping).

Considering these results and the required technical properties for traditional ceramic products [7], all clays are suitable for red stoneware tiles. In fact, up to some amount, the melt formed from the breakdowns of illite and fused feldspar reduced porosity and consequently improved properties. The influence of the neoformed crystalline phases on the properties was almost negligible.

\section{CERAMIC SUITABILITY OF CLAYS IN RELATION TO REPORTED DIAGRAMS}

Based on the representative points of the grain size fractions of clays in the diagram of Fig. 4a, the studied raw materials are inappropriate for structural ceramic products. They rather are suitable for pottery (clay fractions $>60 \mu \mathrm{m})$. The inappropriate use of clays for bricks and tiles is supported by the diagram in Fig. 4b. The representation of the Atterberg's limits of clays in the diagram of Bain and Highly (Fig. 4c) shows that extrusion was an adequate shaping method for all clays. Also, it may allow deducing that clays are convenient for pottery. 

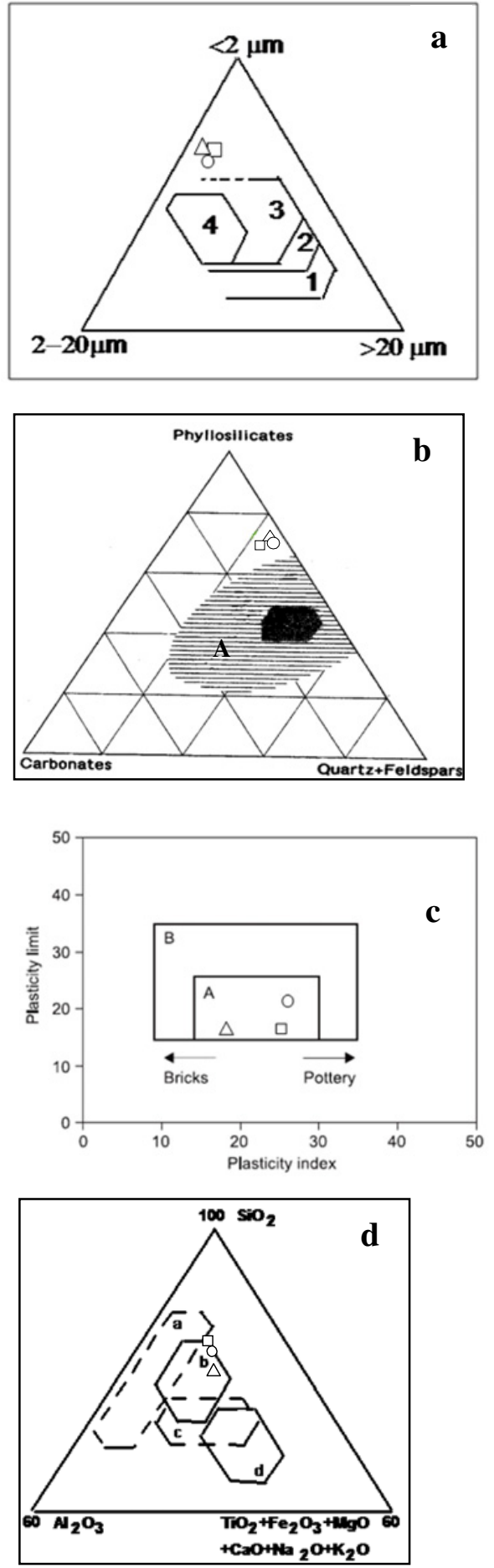

Figure 4. Empirical diagrams defining suitable domains for different types of ceramic products. (a) Diagram of Winkler [10]. (1) common bricks, (2) vertically perforated bricks, (3) roofing tiles and light blocks, (4) thin-walled hollow bricks and blocks. (b) (A) structural clay bodies, (B) clay roofing tiles [11] (c) Diagram of Bain and Highley [12]. Optimum (A) and acceptable (B) domains for clay shaping by extrusion. (d) white (A) and red (B) stoneware tiles; porous tiles (C and D) [13]. $\bigcirc \mathrm{RA} ; \triangle \mathrm{RO} ; \square \mathrm{RS}$.

Taking into consideration the chemical compositions of clays and the ternary diagram in Fig. 4d, the raw clays could be suitable for red stoneware. This result is consistent with the above findings.

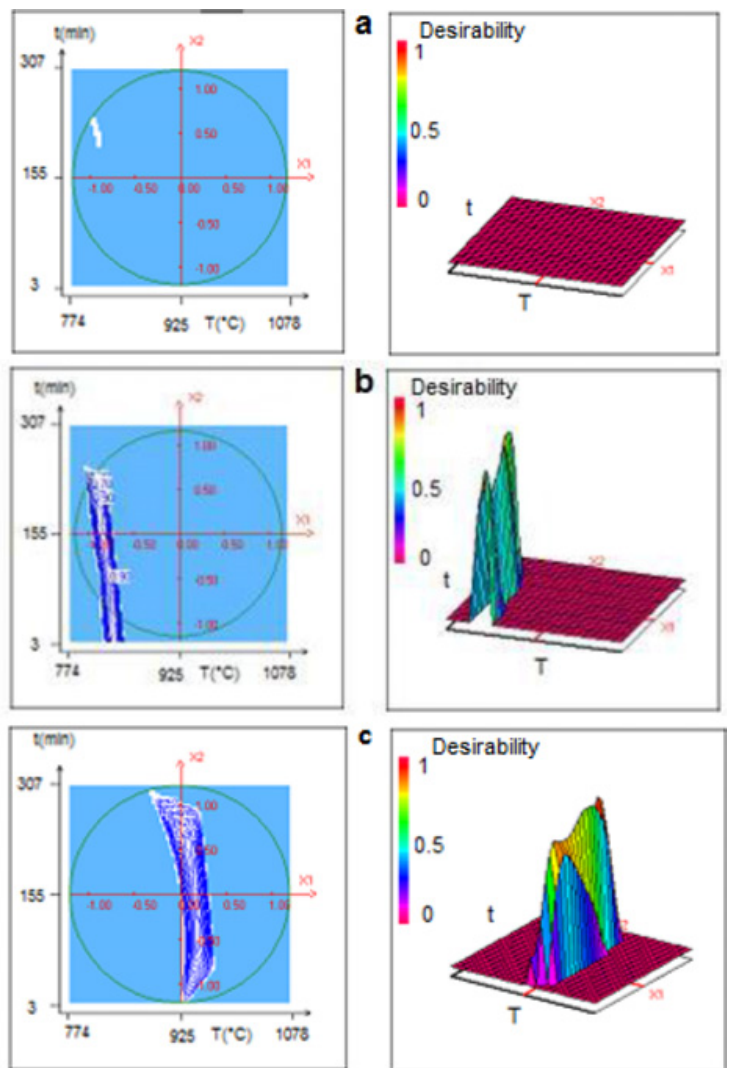

Figure 5. Desirability domains (bi- and tri-dimensional representations) for porous tiles (a), bricks (b) and red stoneware tiles (c).

\section{CERAMIC SUITABILITY OF CLAYS USING RSM}

Considering for instance RS clay, a ceramic property (BS, FS or WA) varied against the coded variables $X_{1}, X_{2}$, and $\mathrm{X}_{3}$, relating to $\mathrm{T}, \mathrm{t}$ and $\mathrm{h}$ (natural factors) respectively, according to the models:

$$
\begin{aligned}
B S= & 32,202+13,773 \mathrm{X}_{1}+1,624 \mathrm{X}_{2}+1,234 \mathrm{X}_{3} \\
& -8,111 \mathrm{X}_{1}^{2}+8,343 \mathrm{X}_{2}^{2}+7,447 \mathrm{X}_{3}^{2}-8,291 \mathrm{X}_{1} \mathrm{X}_{2} \\
& +16,603 \mathrm{X}_{1} \mathrm{X}_{3}+11,229 \mathrm{X}_{2} \mathrm{X}_{3}
\end{aligned}
$$

$W A=6,243-11,775 \mathrm{X}_{1}-1,444 \mathrm{X}_{2}+0,587 \mathrm{X}_{3}$

$$
\begin{aligned}
& +6,289 X_{1}^{2}-1,292 X_{2}^{2}-1,228 X_{3}^{2}+3,397 X_{1} X_{2} \\
& -3,278 X_{1} X_{3}-3,430 X_{2} X_{3}
\end{aligned}
$$

$$
\begin{aligned}
\mathrm{FS}= & 8,022+5,796 \mathrm{X}_{1}^{2}+0,487 \mathrm{X}_{2}-0,355 \mathrm{X}_{3} \\
& -2,726 \mathrm{X}_{1}^{2}+0,012 \mathrm{X}_{2}^{2}+0,289 \mathrm{X}_{3}^{2}-0,497 \mathrm{X}_{1} \mathrm{X}_{2} \\
& +0,009 \mathrm{X}_{1} \mathrm{X}_{3}+0,696 \mathrm{X}_{2} \mathrm{X}_{3} .
\end{aligned}
$$

Details relevant to these models were reported elsewhere $[7,14]$. The comparison of the effects of the factors 
showed that the factors weight increased in the order: $\mathrm{T}>\mathrm{t}>\mathrm{h}$.

Based on the technical requirements for bricks, porous tiles and stoneware tiles [7], and considering the equations (1), (2) and (3) the desirability domains, i.e. the suitable sets of the considered factors, for manufacturing the aforementioned ceramic products were defined using the New Efficient Methodology for Research using Optimal Design (NEMROD) software [15]. Referring to Fig. 5a, the raw clay is not convenient for roofing and porous tiles. However, it could be used for bricks, but the corresponding desirability domain is very narrow (Fig. 5b). In the sight of the results of Fig. 5c, red stoneware tiles could be successfully manufactured. In this case, moderate firing temperatures $\left(\mathrm{T}<950^{\circ} \mathrm{C}\right)$ may be used.

\section{CONCLUSIONS}

Upon heating, the raw clays consisting of high contents of illite and clay fraction $(<2 \mu \mathrm{m})$ were the subject of partial fusion. The melt formation had a major impact on the technical ceramic properties, and consequently influenced the ceramic suitability of clays. The effect of neoformation processes of crystalline phases was insignificant. The use of some reported diagrams allowed to predict the ceramic suitability of clays. However, neither the firing conditions nor the magnitudes of the ceramic properties can be known. The RSM was proven to be a helpful method for assessing the ceramic suitability of clays. As compared to the other methods, it enabled to determine the adequate sets of the operating factors for manufacturing red stoneware tiles.

\section{References}

[1] C.A. Jouenne, Traité de céramiques et matériaux minéraux (Editions Septima, Paris, 1990).

[2] M. Dondi, G. Ercolani, C. Melandri, C. Mingazzini, M. Marsigli, Interceram, 48 (1999).

[3] M. Echajia, S. Kacim, M. Hajjaji, Ind. Ceramics, 27 (2007).

[4] A. Khalfaoui, M. Hajjaji, Appl. Clay Sci., 45 (2009).

[5] W.A.G. Nyakairu, H. Kurzweil, C. Koeberl, J. African Earth Sci., 35 (2002).

[6] A. Khalfaoui, M. Hajjaji, Ceramics - Silikáty 54, 4 (2010).

[7] A. Khalfaoui, M. Hajjaji, S. Kacim, A. Baçaoui, J. Am. Ceram. Soc. 89, 5 (2006).

[8] D. Njoya, M. Hajjaji, A. Baçaoui, D. Njopwouo, Mater. Characterization, 61 (2010).

[9] M. Hajjaji, S. Kacim, M. Boulmane, Appl. Clay Sci., 21 (2002).

[10] H.G.F. Winkler, Ber. Dtsch. Keram. Ges., 31 (1954).

[11] B. Fabbri, M. Dondi, La produzione del laterizio in Italia (Faenza Editrice, Italy 1995).

[12] J.A. Bain, D.E Highley, Proc. Int. Clay Conf. AIPEA, Oxford (1966).

[13] B. Fabbri, C. Fiori, Miner. Petrogr. Acta, 29A (1985).

[14] A. Khalfaoui, Etude du comportement à la cuisson d'une argile locale et d'optimisation des effets de paramètres du cycle thermique par la méthode des surfaces de réponse, $\mathrm{PhD}$ Thesis, Faculté des Sciences Semlalia, Université Cadi Ayyad, No. d'ordre 231 (2008).

[15] D. Mathieu, R. Phan Tan Luu, Software NEMROD. Université d'Aix — Marseille III, France (1980). 